\title{
Three-way interaction effects of workaholism on employee well-being: Evidence from blue-collar workers in New Zealand
}

\author{
JARROd HAAR* AND MAREe ROCHE ${ }^{\dagger}$
}

\begin{abstract}
Workaholism is an important workplace phenomenon that has received less empirical testing than might be expected. This study of $100 \mathrm{New}$ Zealand blue-collar workers tested whether three dimensions of the workaholism triad: work involvement, drive to work and work enjoyment were related to anxiety, depression and insomnia, and in the majority this was supported. Work involvement was positively related to all outcomes, while work enjoyment was negatively related. Drive to work was positively related to anxiety and insomnia only. Overall, consistently, large amounts of variance were explained by the workaholism triad. While previously untested in the literature, a three-way interaction of the workaholism triad was found towards anxiety and insomnia. Overall, higher work involvement was useful in buffering detrimental outcomes for those with either high work involvement or high drive to work, but not both. The present study provides a new way of understanding the effects of workaholism in the workplace.
\end{abstract}

Keywords: workaholism, anxiety, depression, insomnia, three-way interactions

\section{INTRODUCTION}

7 he degree to which people are defining themselves by what they do for a living has never been as prevalent as in today's society (Hakim, 2000). Porter supports this notion stating 'there is a general belief that people currently spend more time than ever engaged in work' (2001: 148). Studies examining the nature of work commitment and more specifically work aspects describe 'workaholism' as an over commitment to work at the expense of a balanced lifestyle (Harpaz \& Snir, 2003), potentially resulting in mental health issues (Goetzel, Long, Ozminkowski, Hawkins, Wang, \& Lynch, 2004). While in New Zealand $17.9 \%$ of workers work $50 \mathrm{hr}$ or more per week and $7 \%$ work over $60 \mathrm{hr}$ per week (Statistics New Zealand, 2008), time at work is not the best indicator of addiction to work - or workaholism - and the detrimental consequences of this behaviour. Although the popular press has paid much attention to workaholism (e.g., Fassel, 1990; Killinger, 1991), Burke and MacDermid stated, 'very little research has been undertaken to further our understanding of it' (1999: 277). Scott, Moore, and Miceli (1997) suggested that fundamental questions relating to definitions and measurement issues still needs further attention. Therefore, the present study seeks to explore workaholism dimensions within a New Zealand organisation to garner a clearer understanding of the relationship between workaholism and well-being outcomes.

* School of Management, College of Business, North Shore City, Auckland, New Zealand

$\dagger$ School of Psychology, Faculty of Arts and Social Sciences, University of Waikato, New Zealand

Corresponding author: E-mail: j.haar@massey.ac.nz; mroche@waikato.ac.nz 


\section{THEORETICAL APPROACHES TO WORKAHOLISM}

Workaholism research has taken several different approaches and has evolved over time. Alternative views of workaholism as either a negative or positive phenomenon have split researchers over their interpretation of the intrinsic motivations driving workaholic behaviour. McMillan and O'Driscoll suggested there is 'conflicting information over the organisational value of workaholism' (2004: 509). Those viewing the behaviour as positive, posit workaholism as a natural desire to work hard (Machlowitz, 1980) or a desire to work hard as its own reward (Cantarow, 1979). Some authors counter this argument and suggest that workaholism is a condition that needs rectifying, such as Cherrington who defined workaholism 'as an irrational commitment to excessive work. Workaholics are unable to take time off or to comfortably divert their interests' (1980: 257), suggesting that working for long hours is an unnatural behaviour. This is a milder interpretation of others who have suggested workaholism is an addiction to work (Killinger, 1991; Robinson, 1996).

Research on workaholism has been hindered by acceptable definitions. Zohar (2006) noted that after 25 years of attention, there is still little consensus regarding a definition and measurement of workaholism. Despite use of the common nomenclature around workaholism, consensus about the meaning of the word and scientific understanding of the implications of workaholism is relatively limited (Spence \& Robbins, 1992; Burke, 1999, 2001; Bonebright, Clay, \& Ankenman, 2000; McMillan, Brady, O’Driscoll, \& Marsh, 2002; Aziz \& Zickar, 2006). McMillan, O’Driscoll, Marsh, and Brady noted that workaholism originated 'from the assumption that excessive working stemmed from an underlying addiction' (2001: 69). Definitional issues have resulted in research diverse in nature and outcome, for example, some report time spent at work as a definition (Garfield, 1987), while others defined workaholism in general terms such as someone who is unable to take time off work (Cherrington, 1980), or, someone who devotes more time and thought to their work than the situation demands (Machlowitz, 1980).

Other researchers have proposed the existence of different types of workaholic behaviour patterns, the antecedents and their outcomes. Spence and Robbins (1992) proposed a workaholic 'triad' based on their concept of workaholism. The triad of workaholism consist of work involvement, feeling driven to work and work enjoyment. Work involvement refers to the extent to which an employee constructively uses their time and dedicates themselves to working productively. Drive to work reflects the individuals' internal motivation and inner pressure to work, and work enjoyment is the degree to which the individual derives pleasure from work. Spence and Robbins (1992) therefore defined the workaholic as a person who 'is highly work involved, feels compelled or driven to work because of inner pressures, and is low in enjoyment of work' (p. 62). For Spence and Robbins, these three components of workaholism could create, using cluster analysis, a number of differing employee profiles: 'Workaholics' were defined as those with high work involvement and drive to work but low work enjoyment; while the 'work enthusiast' was average on work involvement and enjoyment, but low levels of work drive; and the 'enthusiastic workaholic' was above average on all three dimensions. Furthermore, they defined the 'unengaged worker' as representing the opposite to enthusiastic workaholics (low on all three dimensions); while the 'relaxed worker' is below average on work involvement and drive, but above average on enjoyment. Finally, the 'disenchanted worker' is characterised as being below average on work involvement and enjoyment but above average on driven dimension.

Spence and Robbins (1992) used these employee profiles to indicate significant differences towards outcomes, for example, workaholics (above average work involvement and drive to work and below average work enjoyment) reported significantly higher stress than relaxed workers (below average work involvement and drive to work and above average work enjoyment). In the development of their triad, Spence and Robbins suggested that workaholism, like alcoholism, can be described as an addiction 'the workaholic feels driven or compelled to work, not because of external pressures to work, but 
because of inner pressures that make the person feel distressed or guilty about not working' (1992: 162). Further, they describe the workaholic as a person who has a large degree of intensity and involvement in the work itself, rather than workaholism being correlated to the amount of time they devote to work. For example, in terms of work involvement, a person who has high work involvement characteristically involves themselves in productive projects and constructively uses time. Work enjoyment is a reflection of the level of intrinsic meaning a person gains from their work. Therefore, workaholics, in their 'addiction' to their work, tend to be obsessive in their approach to work, and as such are less able to have clear boundaries around work, often holding onto responsibilities and taking on greater workloads, ultimately resulting in feelings of being overwhelmed by these self-imposed responsibilities and the expectations.

Despite the limited research and validation of workaholism (McMillan et al., 2002), the Spence and Robbins (1992) model has been the most frequently used and tested (Burke 1999, 2001; Bonebright, Clay, \& Ankenman, 2000; McMillan et al. 2002; Burgess, Burke, \& Oberklaid, 2006), and the triad interaction of workaholic behaviours has been defined as a syndrome requiring even greater emphasis on research and understanding (Aziz \& Zickar, 2006). The significance of workaholism has found to have implications for both individuals and organisations. Researchers (Spence \& Robbins, 1992; Burgess, Burke, \& Oberklaid, 2006) have found that workaholism manifested itself in terms of less delegation of work, more perfectionist behaviours and the experience of greater job stress. These findings have consequences at the organisational level such that the workaholic is unable to delegate, thus slowing progress and flexibility within the organisation that may present a problem in today's fast pace, competitive environment. Furthermore, this effect may be intensified if the skills of the job are not easily transferable and thus delegated to others. Other research identified that, in addition to the greater prevalence of stress in the workaholic, they experienced more physical ill-health, sickness and psychosomatic symptoms than non-workaholics (Burke, 1999; Burgess, Burke, \& Oberklaid, 2006), with consequences in terms of productivity. Similarly, individual consequences such as feeling driven to work have been correlated to poor emotional well-being (Burke, 1999; Burgess, Burke, \& Oberklaid, 2006). Interestingly, respondents who reported higher levels of work enjoyment did have more positive emotional well-being; however, overall, emotional and physical well-being was reduced for the workaholic (Burke 1999; Burgess, Burke, \& Oberklaid, 2006).

In addition to ill-being (Spence \& Robbins, 1992), employees who exhibit workaholic behaviour are unlikely to enjoy the benefits associated with participating in off-job activities, which assist the individual in coping with and preventing psychological strain (O’Driscoll, Ilgen, \& Hildreth, 1992). The consequence of workaholism, from perfectionist behaviours, increased stress and physical ills, to diminished life, career, purpose and meaning in life and work satisfaction (Burke, 1999, 2001; Burke \& MacDermid, 1999; Bonebright, Clay, \& Ankenman, 2000; Burgess, Burke, \& Oberklaid, 2006), make further investigation of workaholism a priority for research. In addition, research that examines outcomes that may be potential consequences of workaholic behaviour may be beneficial not only in terms of enhanced understanding of the concept, but also in the developing of strategies that can intervene and manage such behaviour (Bonebright, Clay, \& Ankenman, 2000). Moreover, greater validation of workaholism has been called for (McMillan et al., 2002), particularity in two areas: (1) use of wider cultural samples to aid validity and generalisability of findings and (2) research samples that focus on occupations other than white-collar workers (Spence \& Robbins, 1992; Burke, 1999, 2001; Burgess, Burke, \& Oberklaid, 2006).

\section{HYPOTHESES}

The role of workaholism with regard to stress levels and fatigue has been touched upon by several authors, with Spence and Robbins (1992) reporting positive correlations between increased hours and 
workplace demands. In comparisons of workaholics versus non-workaholics, workaholics have been found to experience greater stress (Burke \& MacDermid, 1999; Burke, 2000). Machlowitz (1980) asserted it is the workaholics' attitude to work and not the number of hours worked that differentiate them from other workers. In their triad approach to workaholism, Spence and Robbins (1992) found positive correlations between the work involvement and drive to work dimensions and job stress, although no significant correlations were found between job stress and work enjoyment. It should be noted that working long hours is not a pre-requisite of workaholism and stress, and correlations between hours worked and psychological strain are modest (Sparks, Cooper, Fried, \& Shirom, 1997). This is despite some studies operationalising workaholism as simply total hours worked (e.g., Snir \& Harpaz, 2006). Aziz and Zickar (2006) suggested that this might be due to workaholics creating additional pressure including self-selecting themselves into more demanding and stressful jobs. Scott, Moore, and Miceli (1997) support this, suggesting perfectionist workaholic would be positively related to a number of aspects of ill-being including stress and physical and psychological problems.

The links between workaholism and stress is similarly aligned with psychological well-being (Burke, 2001). Studies using the Spence and Robbins (1992) triad have shown that while work involvement and drive to work are typically positively related to stress and psychological distress, work enjoyment is typically negatively related. Hence, workers who are more involved in their work and feel driven to work are more likely to suffer from stress and poor well-being, while workers who enjoy their work are less likely to feel distress. In addition to psychological distress (specifically anxiety and depression), the present study also test the relationship towards insomnia as this is an outcome that has not been explored in the workaholism literature. Greenberg (2006) noted that insomnia is often a reaction to stress and hence testing this as an outcome of workaholism is appropriate. Insomnia affects up to $17 \%$ of adults in the United States (Johnson, Roehrs, Roth, \& Breslau, 1998), and has been estimated to cost $\$ 100$ billion annually through treatment, lost productivity and accidents (Stoller, 1994), highlighting the importance of testing this aspect of well-being. This leads to the first set of hypotheses:

Hypothesis 1: Work involvement will be positively related to (a) anxiety, (b) depression and (c) insomnia.

Hypothesis 2: Drive to work will be positively related to (a) anxiety, (b) depression and (c) insomnia.

Hypothesis 3: Work enjoyment will be negatively related to (a) anxiety, (b) depression and (c) insomnia.

\section{THREE-WAY INTERACTION EFFECTS OF WORKAHOLISM TRIAD}

There have been calls in the organisational behaviour literature for the need to embrace complexity by exploring interaction effects (Perry-Jenkins, Repetti, \& Crouter, 2000). This is because there is growing recognition that testing interaction effects can clarify and add value to our understanding of established constructs and effects. While still rare in moderation studies, three-way interactions have begun to be explored to gain additional understanding of the interactions between variables (e.g., Duffy, Shaw, Scott, \& Tepper, 2006). Dawson and Richter (2006) noted that three-way interactions are more complex when compared to two-way interactions, and can be utilised to examine the concerted interplay of typologies. Despite the workaholism triad being found to individually link to outcomes, the literature typically fails to test these together as an overall (three-way) interaction effect.

The three-way interaction approach has been seen in the organisational justice literature, where studies have begun to explore the moderating role of the various organisational justice dimensions 
upon each other. Cropanzano, Slaughter, and Bachiochi (2005) argued that dimensions of organisational justice are typically explored separately, without giving enough consideration to moderating effects. They suggested this main effect approach is limited due to the literature asserting that organisational justice dimensions 'should be predicted by the interaction among the three types of fairness' (Cropanzano, Slaughter, \& Bachiochi, 2005: 1172). Similarly, Skarlicki and Folger (1997) found three-way interactions explained a significant amount of variance towards outcomes that were beyond main and two-way interaction effects. In a different vein, Fedor, Caldwell, and Herold (2006) noted their three-way interaction findings were different from their two-way interactions, which would have found similar findings to the literature leading to 'a potentially misleading conclusion' (p. 22). Consequently, three-way interactions allow for more exact understanding of interactions and this must be especially true for the workaholism triad.

As noted above, three-way interactions are useful when we have an understanding of the direct effects of variables (e.g., workaholism dimensions on outcomes), but we do not have a clear understanding of how these dimensions interact with each other. Since work enjoyment is consistently negatively related to the other dimensions in the Spence and Robbins (1992) workaholism triad, a three-way interaction would provide insight into the influence work enjoyment has on work involvement and drive to work. In particular, we might expect the work enjoyment dimension to buffer the associated negative links between work involvement, and drive to work, towards employee well-being. Given that work enjoyment is negatively related to the other workaholism dimensions, we suggest that the three-way interaction effects will be clearly shown with differences between high and low levels of work enjoyment. This leads to the last hypothesis.

Hypothesis 4: There will be a three-way interaction among the workaholism triad towards (a) anxiety, (b) depression and (c) insomnia, with work enjoyment providing significant buffering effects on interactions effects between work involvement and drive to work.

\section{METHOD}

\section{Sample and procedure}

Data were collected from an organisation with 180 employees with multiple working sites in related industries in Auckland, the largest metropolitan city in New Zealand, in the construction industry. Senior managers from these worksites were approached and supported one of the researchers in approaching employees for participating in the survey. All employees were approached in person, had the research outline explained, and were invited to participate in a survey. Approximately 140 employees agreed to participate and surveys were then distributed to these employees through internal mail. A total of 112 responses were received, however, 12 of these were removed due to missing data. All sampled workers were blue-collar employees, with their work typically skilled labour (e.g., forklift driving) and manual labour (lifting). From the entire employee population, a 56\% response rate was gathered $(n=100)$. Participants ranged in age from 18 to 65 years, with an average age of 41 years, with the majority male (89\%). There was a wide representation of ethnicity, with $42 \%$ New Zealand European, $22 \%$ Maori, 28\% Pacific peoples, 3\% Chinese and 5\% Indian. With regard to working hours, the typical working week ranged from 38 to $50 \mathrm{hr}$, while typical overtime worked per week ranged from 0 to $27.5 \mathrm{hr}$.

\section{Measures}

\section{Criterion variables}

Anxiety and depression were measured using 12 items by Axtell, Wall, Stride, Pepper, Clegg, Gardner and Bolden (2002) ( 1 ='never', $5=$ 'all the time'). For each measure, respondents were presented 
with six adjectives and were asked to describe how often these apply to them at work. For each scale, three of the items were reverse coded. Sample items are 'calm' (reverse coded) and 'anxious' for anxiety and 'cheerful' (reverse coded) and depressed for depression. A high score represents increased depression or anxiety. Both scales had strong reliability with Cronbach's $\alpha$ s of 0.87 (anxiety) and 0.92 (depression). Insomnia was measured by four items based on Greenberg (2006) (1 = 'not at all', $5=$ 'to a great extent'). Items followed the stem 'Indicate the extent to which you have experienced each of the following symptoms over the past month' and a sample item is 'difficulty falling asleep'. This measure has a Cronbach's $\alpha$ of 0.92 .

\section{Predictor and moderation variables}

Workaholism was measured with 21 items by Spence and Robbins (1992) (1 = 'strongly disagree', $5=$ 'strongly agree'). The three dimensions of workaholism were explored, and number of items, sample items and reliabilities for the three dimensions were: work involvement 5-items, 'Between my job and other activities I'm involved in I don't have much free time', $\alpha=0.65$; drive to work 7-items, 'I seem to have an inner compulsion to work hard', $\alpha=0.78$; and enjoyment of work 9-items, 'When I get involved in an interesting project it's hard to describe how exhilarated I feel', $\alpha=0.77$.

\section{Control variables}

Similar to other workaholism studies (Burke, Matthiesen, \& Pallesen, 2006; Russo \& Waters, 2006), we controlled for a number of demographic variables: age (number of years), gender ( 1 = 'female', $0=$ 'male'), hours worked (regular work hours per week as per employment contract) and overtime hours worked (average overtime worked per week).

\section{Analysis}

While hierarchical regression analysis has been used to predict outcomes associated with workaholism, the procedures have differed. For example, Russo and Waters (2006) used the different worker types (e.g., workaholic, relaxed worker, etc.) as dummy variables to predict outcomes. However, we used the approach of Burke, Matthiesen, and Pallesen (2006), where workaholism dimensions were used to predict outcomes, as this allows for direct and moderating effects to be tested. For all models, anxiety, depression and insomnia were the criterion variables, and control variables (age, gender, hours worked and overtime hours worked) were entered in Step 1. The three dimensions of workaholism (work involvement, drive to work and work enjoyment) were entered in Step 2 as the predictor variables. To test for moderation, Step 3 held the two-way interactions between the three workaholism triad dimensions (work involvement multiplied by drive to work, work involvement multiplied by work enjoyment and drive to work multiplied by work enjoyment). Step 4 held the three-way interaction with the three workaholism triad dimensions multiplied with each other. In Steps 2 to 4, mean centring of the variables was done (Aiken \& West, 1991).

\section{RESULTS}

Descriptive statistics for all the study variables in study one is shown in Table 1.

Table 1 shows that work involvement is significantly correlated with drive to work $(r=0.66$, $p<.01)$, but not work enjoyment $(r=0.04$, non-significant), while drive to work is significantly correlated with work enjoyment $(r=-0.27, p<.05)$. Work involvement and drive to work are both significantly correlated with anxiety, depression and insomnia (all $r s>0.44$, all $p s<.01$ ), as is work enjoyment (all $r s>-0.34$, all $p s<.01$ ). Finally, the three criterion variables (anxiety, depression and insomnia) are all significantly correlated (all $r s>0.44$, all $p s<.01$ ). 
Jarrod Haar and Maree Roche

Table 1. Descriptive statistics and correlations

\begin{tabular}{|c|c|c|c|c|c|c|c|c|c|c|}
\hline Variables & $M$ & $S D$ & 1 & 2 & 3 & 4 & 5 & 6 & 7 & 8 \\
\hline 1. Hours worked & 43.2 & 3.0 & - & & & & & & & \\
\hline 2. Overtime hours worked & 6.8 & 5.4 & 0.14 & - & & & & & & \\
\hline 3. Work involvement & 3.5 & 0.80 & -0.03 & $0.29 * \star$ & - & & & & & \\
\hline 4. Drive to work & 3.4 & 0.77 & -0.08 & $0.28 * \star$ & $0.66^{\star *}$ & - & & & & \\
\hline 5. Work enjoyment & 2.7 & 0.70 & -0.17 & 0.10 & 0.04 & $-0.27 * \star$ & - & & & \\
\hline 6. Anxiety & 2.5 & 0.86 & $0.22^{\star}$ & 0.20 & $0.55^{\star \star}$ & $0.61^{\star *}$ & $-0.35^{\star \star}$ & - & & \\
\hline 7. Depression & 2.4 & 0.94 & $0.22^{\star}$ & 0.18 & $0.45^{\star \star}$ & $0.44^{\star *}$ & $-0.41 \star \star$ & $0.81 * \star$ & - & \\
\hline 8. Insomnia & 3.3 & 1.1 & 0.08 & 0.06 & $0.45^{\star \star}$ & $0.54^{\star \star}$ & $-0.47^{\star \star}$ & $0.59^{\star \star}$ & $0.45^{\star \star}$ & - \\
\hline
\end{tabular}

Note. $N=100 ;{ }^{\star} p<.05 ;{ }^{\star \star} p<.01$.

\section{Direct effects of workaholism}

Results of the hierarchical regressions for Hypotheses 1 to 3 are shown in Tables 2-4.

The tables show that workaholism triad was significantly associated with anxiety: work involvement $(\beta=0.28, \quad p<.01)$, drive to work $(\beta=0.37, \quad p<.01)$ and work enjoyment $(\beta=-0.26, p<.01)$. These were all in the expected directions and support Hypotheses 1a to 1c. Only two of the workaholism dimensions were significantly associated with depression: work involvement $(\beta=0.38, p<.01)$ and work enjoyment $(\beta=-0.41, p<.001)$, with drive to work $(\beta=0.06)$ being non-significant. The two significant relationships were in the expected directions and provide some support for Hypotheses $2 \mathrm{a}$ and $2 \mathrm{c}$. Finally, the workaholism triad was significantly associated with insomnia: work involvement $(\beta=0.31, p<.01)$, drive to work $(\beta=0.24, p<.05)$ and work enjoyment $(\beta=-0.44, p<.001)$. These were all in the expected directions and support Hypotheses 3a to 3c. From the $R^{2}$ change figures in Step 2, we see that the workaholism triad account for very large amounts of overall variance: $44 \%$ for anxiety $(p<.001), 34 \%$ for depression $(p<.001)$ and $48 \%$ for insomnia $(p<.001)$.

\section{Three-way interaction effects of workaholism triad}

The tables also show that the workaholism triad interacted significantly with two of the three outcomes. When anxiety is the criterion variable, there is a significant three-way interaction between work involvement $\times$ drive to work $\times$ work enjoyment $(\beta=0.30, p<.01)$. From the $R^{2}$ change figures in Step 4, we see the workaholism triad three-way interaction accounts for an additional $4 \%$ of the variance $(p<.01)$ towards anxiety, which is over and above the three significant two-way interactions that accounted for an extra $6 \%(p<.01)$ of the variance (in Step 3). When depression is the criterion variable, there is not a significant three-way interaction between work involvement $X$ drive to work $\times$ work enjoyment $\left(\beta=0.16\right.$, non-significant), with the $R^{2}$ change (Step 4) indicating only a $1 \%$ increase in the total variance. However, in Step 3 there are three significant two-way interactions that accounted for an extra 18\% $(p<.001)$ of the variance. Finally, when insomnia is the criterion variable, there is a significant three-way interaction between work involvement $X$ drive to work $\times$ work enjoyment $(\beta=0.45, p<.001)$. From the $R^{2}$ change figures in Step 4 , we see that the workaholism triad three-way interaction accounts for an additional $10 \%$ of the variance $(p<.001)$ towards insomnia, which is over and above the two significant two-way interactions that accounted for an extra $4 \%(p<.1)$ of the variance (in Step 3). Overall, these findings support Hypotheses $4 \mathrm{a}$ and $4 \mathrm{c}$ only. 
TABLe 2. Regression COefFICIENTS For ANXIETY

\begin{tabular}{|c|c|c|c|c|}
\hline \multirow[b]{2}{*}{ Variables } & \multicolumn{4}{|c|}{ Models with anxiety } \\
\hline & $\begin{array}{l}\text { Step } 1 \\
\text { Controls }\end{array}$ & $\begin{array}{c}\text { Step } 2 \\
\text { Predictors }\end{array}$ & $\begin{array}{c}\text { Step } 3 \\
\text { Two-way } \\
\text { interactions }\end{array}$ & $\begin{array}{c}\text { Step } 4 \\
\text { Three-way } \\
\text { interactions }\end{array}$ \\
\hline Age & 0.09 & 0.09 & 0.08 & 0.12 \\
\hline Gender & 0.05 & 0.10 & 0.06 & 0.01 \\
\hline Hours worked & $0.22^{\star}$ & $0.22^{\star \star}$ & $0.23^{\star \star}$ & $0.24^{\star \star}$ \\
\hline Overtime hours worked & 0.12 & -0.04 & -0.14 & -0.13 \\
\hline Work involvement & & $0.28 * \star$ & $0.32^{\star \star}$ & $0.35^{\star \star \star}$ \\
\hline Drive to work & & $0.37^{\star \star}$ & $0.35^{\star \star}$ & $0.27^{\star}$ \\
\hline Work enjoyment & & $-0.26^{\star \star}$ & $-0.28 \star \star$ & $-0.39 * \star \star$ \\
\hline Work involvement $\times$ drive to work & & & $0.14^{\star}$ & $0.28^{\star \star}$ \\
\hline Work involvement $\times$ work enjoyment & & & $-0.19 *$ & 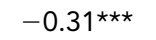 \\
\hline Drive to work $\times$ work enjoyment & & & $0.16^{*}$ & $0.15^{\star}$ \\
\hline Work involvement $\times$ drive to work $\times$ work enjoyment & & & & $0.30 \star \star$ \\
\hline$R^{2}$ change & 0.09 & $0.44^{\star \star \star}$ & $0.06^{\star}$ & $0.04^{\star \star}$ \\
\hline Total $R^{2}$ & 0.09 & 0.53 & 0.59 & 0.63 \\
\hline Adjusted $R^{2}$ & 0.05 & 0.49 & 0.53 & 0.58 \\
\hline F statistic & 2.058 & $13.194^{\star \star \star}$ & $11.217^{\star \star \star}$ & $12.033^{\star \star *}$ \\
\hline
\end{tabular}

Note. ${ }^{\star} p<.05 ;{ }^{\star \star} p<.01 ;{ }^{\star \star \star} p<.001$ : standardized regression coefficients, all significance tests were single-tailed.

TABLE 3. REgRESSION COEFFICIENTS FOR DEPRESSION

\begin{tabular}{|c|c|c|c|c|}
\hline \multirow[b]{2}{*}{ Variables } & \multicolumn{4}{|c|}{ Models with depression } \\
\hline & $\begin{array}{l}\text { Step } 1 \\
\text { Controls }\end{array}$ & $\begin{array}{c}\text { Step } 2 \\
\text { Predictors }\end{array}$ & $\begin{array}{c}\text { Step } 3 \\
\text { Two-way } \\
\text { interactions }\end{array}$ & $\begin{array}{c}\text { Step } 4 \\
\text { Three-way } \\
\text { interactions }\end{array}$ \\
\hline Age & 0.04 & 0.05 & 0.03 & 0.05 \\
\hline Gender & -0.02 & 0.04 & -0.04 & -0.06 \\
\hline Hours worked & $0.23^{\star}$ & 0.17 & $0.20 *$ & $0.20 \star \star$ \\
\hline Overtime hours worked & 0.11 & 0.03 & -0.15 & -0.14 \\
\hline Work involvement & & $0.38^{\star \star}$ & $0.46^{\star \star \star}$ & $0.48^{\star \star \star}$ \\
\hline Drive to work & & 0.06 & 0.03 & -0.02 \\
\hline Work enjoyment & & $-0.41 * \star \star$ & $-0.45^{\star \star \star}$ & 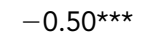 \\
\hline Work involvement $\times$ drive to work & & & $0.25^{\star \star}$ & $0.32^{\star \star \star}$ \\
\hline Work involvement $\times$ work enjoyment & & & $-0.30 * \star \star$ & $-0.36^{\star \star \star}$ \\
\hline Drive to work $\times$ work enjoyment & & & 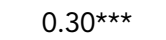 & $0.30^{\star \star \star}$ \\
\hline Work involvement $\times$ drive to work $\times$ work enjoyment & & & & 0.16 \\
\hline$R^{2}$ change & 0.07 & $0.34^{\star \star \star}$ & $0.18 * \star \star$ & 0.01 \\
\hline Total $R^{2}$ & 0.07 & 0.41 & 0.59 & 0.61 \\
\hline Adjusted $R^{2}$ & 0.03 & 0.36 & 0.54 & 0.55 \\
\hline F statistic & 1.631 & $8.223^{\star \star \star}$ & $11.533^{\star \star \star}$ & $10.871 * \star \star$ \\
\hline
\end{tabular}

Note. ${ }^{\star} p<.05 ;{ }^{\star \star} p<.01 ;{ }^{\star \star \star} p<.001$ : standardized regression coefficients, all significance tests were single.

To facilitate interpretation of the significant moderator effects, interactions are presented in Figures 1 and 2, using the three-way interaction graph and simple slopes test results (Dawson \& Richter, 2006) are shown in Table 5. 
TABLE 4. RegRession COEFFICIENTS FOR INSOMNIA

\begin{tabular}{|c|c|c|c|c|}
\hline \multirow[b]{2}{*}{ Variables } & \multicolumn{4}{|c|}{ Models with insomnia } \\
\hline & $\begin{array}{l}\text { Step } 1 \\
\text { Controls }\end{array}$ & $\begin{array}{c}\text { Step } 2 \\
\text { Predictors }\end{array}$ & $\begin{array}{c}\text { Step } 3 \\
\text { Two-way } \\
\text { interactions }\end{array}$ & $\begin{array}{c}\text { Step } 4 \\
\text { Three-way } \\
\text { interactions }\end{array}$ \\
\hline Age & 0.01 & 0.04 & 0.04 & 0.10 \\
\hline Gender & 0.16 & $0.22^{\star \star}$ & $0.19^{*}$ & 0.12 \\
\hline Hours worked & 0.09 & 0.05 & 0.06 & 0.07 \\
\hline Overtime hours worked & 0.02 & -0.09 & -0.15 & -0.13 \\
\hline Work involvement & & $0.31^{\star \star}$ & $0.33^{\star \star}$ & $0.38^{\star \star \star}$ \\
\hline Drive to work & & $0.24^{\star}$ & $0.25^{\star}$ & 0.13 \\
\hline Work enjoyment & & $-0.44^{\star \star \star}$ & $-0.44^{\star \star \star}$ & $-0.59^{\star \star \star}$ \\
\hline Work involvement $\times$ drive to work & & & $0.15^{\star}$ & $0.36 * \star \star$ \\
\hline Work involvement $\times$ work enjoyment & & & -0.05 & $-0.23^{\star \star}$ \\
\hline Drive to work $\times$ work enjoyment & & & 0.14 & 0.13 \\
\hline Work involvement $x$ drive to work $\times$ work enjoyment & & & & $0.45^{\star \star \star}$ \\
\hline$R^{2}$ change & 0.04 & $0.48^{\star \star \star}$ & 0.04 & $0.10^{\star \star \star}$ \\
\hline Total $R^{2^{2}}$ & 0.04 & 0.51 & 0.56 & 0.65 \\
\hline Adjusted $R^{2}$ & 0.00 & 0.47 & 0.50 & 0.61 \\
\hline F statistic & 0.846 & $12.407^{\star \star \star}$ & $9.964^{\star * \star}$ & $13.429^{* \star \star}$ \\
\hline
\end{tabular}

Note. ${ }^{\star} p<.05 ;{ }^{\star \star} p<.01 ;{ }^{\star \star \star} p<.001$ : standardized regression coefficients, all significance tests were single.

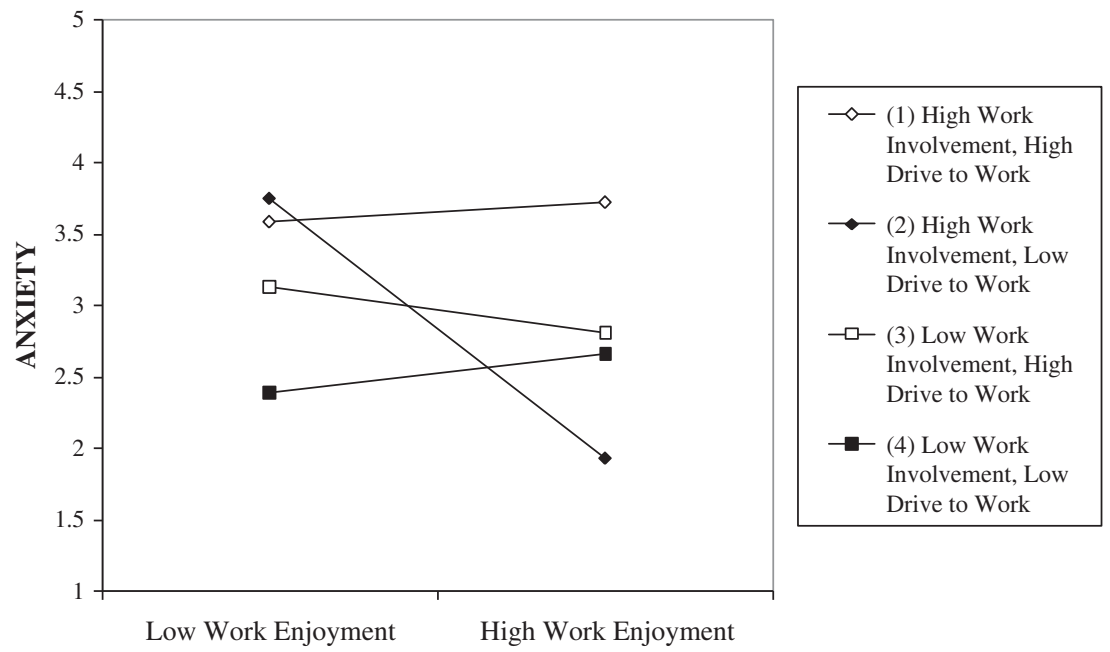

FIGURE 1. THREE-WAY INTERACTION PLOT OF WORK INVOLVEMENT $\times$ DRIVE TO WORK $\times$ WORK ENJOYMENT WITH ANXIETY AS DEPENDENT VARIABLE

Dawson and Richter noted that their three-way interaction simple slopes test allows 'the researcher to test each possible combination of pairs of simple slopes for statistical significance' (2006: 919), which has previously not been available under standard approaches to three-way interactions. The simple slope tests show there are significant differences in slopes for anxiety and insomnia.

Plotting the interaction terms (Figure 1) shows that respondents reporting high work enjoyment report the highest anxiety when work involvement and drive to work is high, but respondents report 


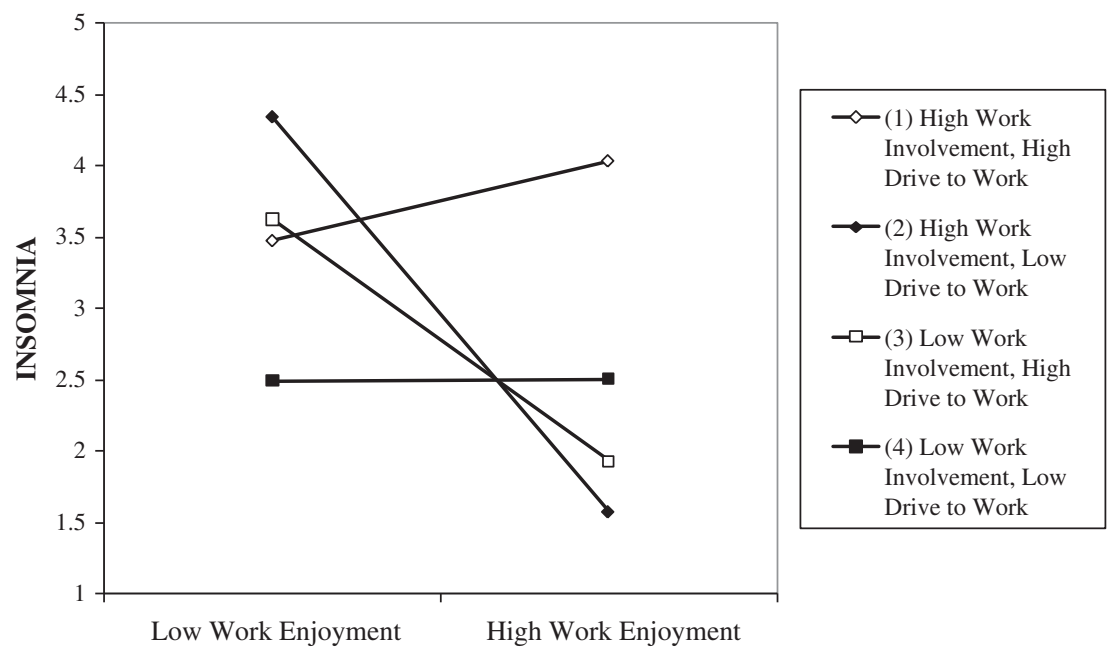

FIGURE 2. THREE-WAY INTERACTION PLOT OF WORK INVOLVEMENT $\times$ DRIVE TO WORK $\times$ WORK ENJOYMENT WITH INSOMNIA AS DEPENDENT VARIABLE

TABLE 5. SLOPE DIFFERENCES TEST FOR ANXIETY AND INSOMNIA

\begin{tabular}{|c|c|c|c|c|}
\hline \multirow[b]{2}{*}{ Pair of slopes } & \multicolumn{2}{|c|}{ Anxiety } & \multicolumn{2}{|c|}{ Insomnia } \\
\hline & $\begin{array}{c}t \text {-value for slope } \\
\text { difference }\end{array}$ & $\begin{array}{l}p \text {-value for slope } \\
\text { difference }\end{array}$ & $\begin{array}{l}\text { t-value for slope } \\
\text { difference }\end{array}$ & $\begin{array}{c}p \text {-value for slope } \\
\text { difference }\end{array}$ \\
\hline (1) and (2) & 3.458 & .001 & 4.437 & .000 \\
\hline (1) and (3) & 1.150 & .253 & 3.988 & .000 \\
\hline (1) and (4) & -0.340 & .735 & 0.987 & .327 \\
\hline (2) and (3) & -2.319 & .023 & -1.227 & .223 \\
\hline (2) and (4) & -3.020 & .003 & -3.168 & .002 \\
\hline (3) and (4) & -1.054 & .295 & -2.288 & .025 \\
\hline
\end{tabular}

Note. Analysis was conducted according to http://www.jeremydawson.co.uk/slopes.htm (12 June 2009).

the lowest anxiety when their work involvement is high but drive to work is low. This later group of employees report significantly lower anxiety levels than employees with similar levels of work involvement (high) and drive to work (low) but low work enjoyment, supporting the importance of high work enjoyment for this particular group of employees.

Plotting the interaction terms (Figure 2) illustrates similar effects as Figure 1 (anxiety), with respondents with high work enjoyment reporting the highest insomnia when work involvement and drive to work are high, compared to respondents with the lowest insomnia levels when work involvement is high but drive to work is low. As with Figure 1, this later group of employees report significantly lower insomnia levels than employees with similar levels of work involvement (high) and drive to work (low) but low work enjoyment, supporting the importance of high work enjoyment for this particular group of employees.

The overall strength of the moderation models for well-being outcomes were significant and substantial: anxiety $\left(R^{2}=0.63, F=12.033, p<.001\right)$, depression $\left(R^{2}=0.61, F=10.871, p<.001\right)$ and insomnia $\left(R^{2}=0.65, F=13.429, p<.001\right)$. Finally, the variance inflation factors were examined 
for evidence of multicollinearity, which can be detected when the variance inflation factors values equal 10 or higher (Ryan, 1997), with little evidence (all scores were below 2.7).

\section{DISCUSSION}

Using the existing Spence and Robbins profile typologies, our findings show that towards anxiety and insomnia, those with the highest levels of these mental health issues are enthusiastic workaholics, followed closely by workaholics, indicating that those with a 'workaholic' nature are the most likely to have poor well-being. This is consistent with the workaholism literature and our understanding of workaholics. Importantly, it appears that being enthusiastic about work is no buffer towards the detrimental links to well-being, highlighting the danger to employees who 'work too much' while also enjoying their work.

Those with high work involvement and high work enjoyment but low drive to work (called work enthusiasts) appear to be the best placed profile from our three-way interactions, with these workers reporting significantly lower anxiety and insomnia when compared to all others. Relaxed workers (high enjoyment but low work involvement and drive to work) and unengaged workers (low on all triad dimensions) also report low levels anxiety and insomnia, consistently at the bottom end of graphed effects. The final profile of disenchanted worker (high drive to work but low work involvement and work enjoyment) reports mid-level anxiety and insomnia.

In addition to the existing typologies, which Spence and Robbins (1992) created from the various options aligned with their workaholism triad, the original cluster analysis resulted in only six profiles, which is not an exact match for all potential combinations. For example, there is no associated profile for the type of workers with high drive to work and high work enjoyment but low involvement. Our findings suggest that there are strong benefits to well-being (especially insomnia) by having such a profile and we categorise these as disengaged enthusiast. That is someone who enjoys work and is driven, but does not dedicate themselves to working productively. Finally, there is no profile for a worker with low drive and enjoyment but high involvement, which we term a hopeless workaholic. Our interactions showed this profile had the worst outcomes with the highest anxiety and insomnia, further reinforces the negative workaholic nature. We suggest that aligning our three-way interaction findings with Spence and Robbins (1992) profiles is imperfect, but the use of their initial profile typologies is of some guidance when interpreting the above interactions.

The present study also sought to test Spence and Robbins (1992) workaholism triad in order to build our understanding of the links between workaholism dimensions and employee well-being. In addition to anxiety and depression outcomes, the present study expanded outcomes explored in the workaholism literature by adding insomnia. This is important as Ferrie, Shipley, Marmot, Stansfield and Davey-Smith (1998) noted that insomnia is a frequent reaction to stress, and given the links between workaholism and stress, it was appropriate to test insomnia as a potential outcome of the workaholism triad. Overall, there were strong and consistent findings between workaholism dimensions and outcomes. Of the dimensions linked positively with outcomes, work involvement was a consistent predictor to all three outcomes, while drive to work was linked to all but depression. Consistently, work enjoyment was negatively linked with all outcomes, reinforcing that not all dimensions of workaholism are detrimental, which aligns with the workaholism triad. Consequently, we have strong support for the Spence and Robbins (1992) workaholism triad providing insight into employee well-being, albeit with its current limited typologies and profiles. Overall, our findings support other studies that have explored the workaholism triad amongst professionals, potentially highlight the universality of the workaholism triad towards understanding employee well-being given our blue-collar sample. 
To our knowledge this is the first study that has explored three-way interactions amongst the workaholism triad. As noted by Fedor, Caldwell, and Herold (2006), three-way interactions might also produce results that differ from two-way interactions, further enhancing the benefits of three-way interactions. While there were no significant three-way interaction effects towards depression, there were strong effects towards anxiety and insomnia. In both models, the three-way interaction produced significant effects over and above the two-way interactions, accounting for an extra $4 \%$ of variance for anxiety and a larger $10 \%$ additional variance for insomnia. Interpreting the graphed effects shows that higher work enjoyment has positive effects towards workers with either high work involvement or high drive to work, but does not buffer anxiety or insomnia if both of these workaholism dimensions are high or low. The most dramatic effects are for those with high work involvement and low drive to work, which shows very significant reductions in anxiety and insomnia.

Overall, our findings suggest being less involved or driven appears consistently to link with higher well-being. Importantly, it appears that employees can still be highly involved or highly driven in their work and still have good well-being, and this is especially so if they enjoy their work. However, as noted above, high work involvement and drive to work appears the most detrimental dimensions towards well-being, and enjoying work does not provide any buffer for these types of workers. The reasons they might produce the strongest detrimental effects towards well-being is because these workers will continue to keep working even when they are suffering large amounts of anxiety and insomnia because they still 'love their job'. In effect, while those who are driven or highly involved are able to slow down or take a break from the demands of the job, these workaholics may not know when to stop.

In addition, we also tested claims of Fedor, Caldwell, and Herold (2006) that three-way interactions could provide different results to two-way interactions. As such, we graphed two-way interaction effects for anxiety (not shown) of work enjoyment buffering the effects of work involvement and then drive to work, as a comparison test. With work involvement, the lowest anxiety reported is by employees with high work involvement and low work enjoyment while, with regard to drive to work, the lowest anxiety is by employees with high work enjoyment and low drive to work. Overall, these two-way interaction effects show that work enjoyment is more beneficial towards drive to work. However, the three-way interactions indicate that work enjoyment is most detrimental to those with high work involvement and high drive to work, which we could not equally interpret with only the two-way interactions. This reinforces the ability of three-way interactions to provide more accurate interpretation of effects than two-way interactions.

\section{Implications}

There are a number of implications from the present study. First, methodologically, using the workaholism triad in a three-way interaction has been neglected in the literature. For example, the literature often follows the approach of Spence and Robbins (1992) where workaholism triad dimensions create profiles, which in turn are then analysed (e.g., ANOVA) towards outcomes. The present study supports the analysis of interaction effects between workaholism dimensions, as these were highly significant in both two-way and three-way interactions. In particular, the three-way interactions between the workaholism triad created a unique perspective towards workaholism, which has previously not been understood, with the role work enjoyment may play in reducing or not reducing employee well-being. We encourage other studies to explore interaction effects to facilitate greater understanding in the literature towards outcomes, including other outcomes such as job satisfaction. Furthermore, we suggest that including a greater range of typologies found to be significant in our interaction results may garner greater insights into the consequences of workaholism, especially related to how the triad dimensions work in combination. 
Second, from an employer and employee perspective, it is important to note the detrimental influence high work involvement and high drive to work can have on the outcomes explored here. While we might assume that high work enjoyment might negate or buffer detrimental effects, there is no evidence of this in the present study, which suggests that employees with high work enjoyment are not as able to buffer the links between involvement and drive towards anxiety and insomnia. As such, having high enjoyment towards one's job is not a panacea for employees, who may still have reduced well-being if they are too involved and driven to their work.

Overall, the present study provides a marker for employees and their employers towards those exhibiting workaholic tendencies. However, the study also provides some areas of hope. We find that those who are either highly involved in their work or highly driven do register greater reductions in anxiety and insomnia through higher work enjoyment. This may provide an avenue for employers towards cautioning employees who are too highly involved in their work and driven. Whether employer-based interventions towards reducing one of these dimensions (work involvement or drive to work) is possible is worthy of further research, and an area where employers might be able to limit the enthusiasm of workaholics to ensure their long-term health and well-being is maintained.

Future research might seek to explore the three-way interaction approach towards employee performance. What is unclear from the present study is how the workaholism triad influences performance. For example, is there any difference in performance between those with high work involvement or drive to work and those who are high on both of these dimensions? This is important because we found those high on both these dimensions experienced the most detrimental outcomes, with high work enjoyment leading to further complications. By understanding the three-way interactions towards performance, employers and employees might understand better ways to achieve performance while maintaining well-being. If work enthusiasts are more productive than workaholics then clearly the terminology of workaholics might be made more negative, rather than being intuitively linked with high performance. Further evidence is needed to clarify these links.

The present study also has a number of strengths regarding its sample. To date, workaholism studies have focused predominantly on white-collar workers, and a gap exists in testing these workaholism dimensions towards blue-collar workers. Furthermore, some economies have labour shortages towards blue-collar workers; warranting greater exploration of this employee group. For example, the New Zealand workforce in July 2011 is reporting shortages in both skilled and unskilled workers (New Zealand Department of Labour, 2011). The present study indicates that 'blue-collar' workers can report similarly detrimental influences from the workaholism triad, suggesting workaholism is not just a white-collar phenomenon. Similarly, the literature has lacked a representative cultural sample, with most studies based on a high proportion of New Zealand European employees (e.g., Bonebright, Clay, \& Ankenman, 2000, 96\% New Zealand European; Porter, 2001, 75\% New Zealand European) and thus our diverse sample aids in the generalisability of findings. The present study included a wide range of ages, working hours and a wide range of ethnicities, including only $42 \%$ New Zealand European and $>20 \%$ amongst Maori and Pacific peoples and the focus on a blue-collar workforce shows that the workaholism dimensions are applicable to a wider range of workers than previously explored.

\section{Limitations}

Finally, there are a number of limitations that need to be raised. First, there is still debate in the workaholism literature about the triad offered by Spence and Robbins (1992). For example, McMillan et al. (2002) suggested that the triad should have only two dimensions, with work involvement being removed. However, the present study did find consistent effects from work involvement towards all outcomes, further reinforcing the original dimensions. Whether future 
researchers utilise all three dimensions or other approaches, the need for interaction effects is clearly important, and we encourage more interaction studies, irrespective of the number of dimensions utilised. Another limitation of the present study is its blue-collar, single organisation focus. While we have noted the importance of expanding workaholism studies to blue-collar workers, further studies on a wider type of organisation with a greater sample size is required to enhance the generalisability of our findings. Furthermore, there is always a potential limitation due to under specification of models, for example, through other constructs influencing outcomes (e.g., job insecurity). However, all models achieved very high variance (61-65\%) suggesting that within this group of employees, the workaholism triad accounts for the majority of variance towards well-being. Future research may also want to extend the predictors to ensure other potentially competing variables are considered. Finally, our measure of work involvement achieved an internal reliability of only 0.65 , which is slightly below the acceptable threshold of 0.70 (Nunnally, 1978). However, this is similar to other studies where $\alpha$ s have ranged from 0.65 to 0.69 (e.g., Spence \& Robbins, 1992; Burke, 2001; Burgess, Burke, \& Oberklaid, 2006; Russo \& Waters, 2006) that might indicate this is related to the measure itself. Similarly, other studies have produced $\alpha$ s for the work involvement measure which are far worse but still used (e.g., 0.46, Burke, Matthiesen, \& Pallesen, 2006). Consequently, while this measure is slightly below acceptable standards it does appear to be robust when compared to the majority of the literature.

\section{Conclusions}

Overall, the present study offers a number of important contributions. The main contribution is how the three-way interactions highlighted the importance that interaction studies may provide to our understanding of workaholism. The three-way interactions allowed for the interplay of typologies to be tested and supported Fedor, Caldwell, and Herold (2006) regarding three-way interactions providing different findings than two-way interactions. Our findings would have been different had we stopped at two-way interactions, which would have made interpretations and recommendations flawed. There is a need for greater replication to confirm these effects, and we also encourage researchers to test for differences from two-way interactions to determine whether differences may result. Our study of blue-collar workers with diverse ethnicities also provides a difference from other workaholism studies and highlights the need for further studies to understand workaholism dimensions amongst employees from all professions and industries.

\section{REFERENCES}

Aiken, L. G., \& West, S. G. (1991). Multiple regression: Testing and interpreting interactions. Newbury Park, CA: Sage. Axtell, C., Wall, T., Stride, C., Pepper, K., Clegg, C., Gardner, P., \& Bolden, R. (2002). Familiarity breeds content:

The impact of exposure to change on employee openness and well-being. Journal of Occupational and

Organisational Psychology, 75, 217-231.

Aziz, S., \& Zickar, M. J. A. (2006). Cluster analysis investigation of workaholism as a syndrome. Journal of Occupational Health Psychology, 11(1), 52-62.

Bonebright, C. A., Clay, D. L., \& Ankenman, R. D. (2000). The relationship of workaholism with work-life conflict, life satisfaction, and purpose in life. Journal of Counselling Psychology, 47(4), 469-477.

Burgess, Z., Burke, R. J., \& Oberklaid, F. (2006). Workaholism among Australian psychologists: Gender differences. Equal Opportunities International, 25(1), 48-59.

Burke, R. J. (1999). Workaholism among women managers: Work and life satisfaction and psychological well-being. Equal Opportunities International, 18(7), 25-37.

Burke, R. J. (2000). Workaholism in organizations: Psychological and physical well-being consequences. Stress Medicine, 16(1), 11-16. 
Burke, R. J. (2001). Predictors of workaholism components and behaviours. International Journal of Stress Management, 8(2), 113-127.

Burke, R. J., \& MacDermid, G. (1999). Are workaholics job satisfied and successful in their careers? Career Development International, 4(5), 277-282.

Burke, R. J., Matthiesen, S. B., \& Pallesen, S. (2006). Workaholism, organisational life and well-being of Norwegian nursing staff. Career Development International, 11(5), 463-477.

Cantarow, E. (1979). Women workaholics. Mother Jones, 6, 56-58.

Cherrington, D. J. (1980). The Work Ethic. New York, NY: American Management Association.

Cropanzano, R., Slaughter, J. E., \& Bachiochi, P. D. (2005). Organisational justice and black applicants' reactions to affirmative action. Journal of Applied Psychology, 90(6), 1168-1184.

Dawson, J. F., \& Richter, A. W. (2006). Probing three-way interactions in moderated multiple regression: Development and application of a slope difference test. Journal of Applied Psychology, 91(4), 917-926.

Duffy, M. K., Shaw, J. D., Scott, K. L., \& Tepper, B. J. (2006). The moderating roles of self-esteem and neuroticism in the relationship between group and individual undermining behaviour. Journal of Applied Psychology, 91(5), $1066-1077$.

Fassel, D. (1990). Working ourselves to death: The high costs of workaholism, the rewards of recovery. San Francisco, CA: HarperCollins.

Fedor, D. B., Caldwell, S., \& Herold, D. M. (2006). The effects of organisational changes on employee commitment: A multilevel investigation. Personnel Psychology, 59, 1-29.

Ferrie, J. E., Shipley, M. J., Marmot, M. G., Stansfield, S., \& Davey-Smith, G. (1998). The health effects of major organisational change and job insecurity. Social Science and Medicine, 46, 243-254.

Garfield, C. A. (1987). Peak performers: The heroes of American business. New York, NY: William Morrow.

Greenberg, J. (2006). Losing sleep over organisational injustice: Attenuating insomniac reactions to underpayment inequity with supervisory training in interactional justice. Journal of Applied Psychology, 91(1), 58-69.

Goetzel, R. Z., Long, S. R., Ozminkowski, R. J., Hawkins, K., Wang, S., \& Lynch, W. (2004). Health, absence, disability and presenteeism cost estimates of certain physical and mental health conditions affecting US employers. Journal of Occupational and Environmental Medicine, 46(4), 398-412.

Hakim, C. (2000). Work-lifestyle choices in the 21st century. Oxford, UK: Oxford University Press.

Harpaz, I., \& Snir, R. (2003). Workaholism: Its definition and nature. Human Relations, 56(3), 291-319.

Johnson, E. O., Roehrs, T., Roth, T., \& Breslau, N. (1998). Epidemiology of alcohol and medication as aids to sleep in early adulthood. Sleep, 21, 178-186.

Killinger, B. (1991). Workaholics: The respectable addicts. New York, NY: Simon \& Schuster.

Machlowitz, M. (1980). Workaholics: Living with them, working with them. Reading, MA: Addison-Wesley.

McMillan, L. H. W., Brady, E. C., O’Driscoll, M. P., \& Marsh, N. V. (2002). A multifaceted validation study of Spence and Robbins (1992) workaholism battery. Journal of Occupational and Organisational Psychology, 75, 357-368.

McMillan, L. H. W., \& O'Driscoll, M. P. (2004). Workaholism and health: Implications for organisations. Journal of Organisational Change Management, 17(5), 509-519.

McMillan, L. H. W., O’Driscoll, M. P., Marsh, N. V., \& Brady, E. C. (2001). Understanding workaholism: Data synthesis, theoretical critique, and future design strategies. International Journal of Stress Management, 8(2), 69-91.

New Zealand Department of Labour (2011). Labour Market Update - July 2011. Wellington, New Zealand: Department of Labour.

Nunnally, J. C. (1978). Psychometric Theory. New York, NY: McGraw-Hill.

O’Driscoll, M. P., Ilgen, D. R., \& Hildreth, K. (1992). Time devoted to job and off-job activities inter role conflict, and affective experiences. Journal of Applied Psychology, 77, 272-279.

Perry-Jenkins, M., Repetti, R. L., \& Crouter, A. C. (2000). Work and family in the 1990s. Journal of Marriage and Family, 62, 981-998.

Porter, G. (2001). Workaholic tendencies and the high potential for stress among co-workers. International Journal of Stress Management, 8(2), 147-164.

Robinson, B. E. (1996). Concurrent validity of the work addiction and family functioning: Clinical implications for marriage and family therapists. Journal of Family Psychotherapy, 7(3), 13-29.

Russo, J. A., \& Waters, L. E. (2006). Workaholic worker type differences in work-family conflict: The moderating role of supervisor support and flexible work scheduling. Career Development International, 11(5), 418-439. 
Ryan, T. P. (1997). Modern regression methods. New York, NY: Wiley.

Scott, K. S., Moore, K. S., \& Miceli, M. P. (1997). An exploration of the meaning and consequences of workaholism. Human Relations, 50, 287-314.

Skarlicki, D. P., \& Folger, R. (1997). Retaliation in the workplace: The roles of distributive, procedural, and interactional justice. Journal of Applied Psychology, 82, 434-443.

Snir, R., \& Harpaz, I. (2006). The workaholism phenomenon: A cross-national perspective. Career Development International, 11(5), 374-393.

Sparks, K., Cooper, C., Fried, Y., \& Shirom, A. (1997). The effects of hours of work on health: A meta-analytic review. Journal of Occupational and Organisational Psychology, 70, 391-408.

Spence, J. T., \& Robbins, A. S. (1992). Workaholism: Definition, measurement, and preliminary results. Journal of Personality Assessment, 58(1), 160-178.

Statistics New Zealand (2008). Labour market statistics: 2007. Wellington, New Zealand: Statistics New Zealand.

Stoller, M. K. (1994). Economic effects of insomnia. Clinical Therapy, 16, 873-897.

Zohar, D. (2006). On the vicissitudes of the study of workaholism: A construct at a crossroad. Career Development International, 11(5), 478-482. 